\title{
Discussion on significance of career planning for college students on ideological and political education
}

\author{
Ting Li \\ Chongqing Electric Power College, 400030, China
}

Keywords: college student; career planning; ideological and political education; significance

Abstract: career planning for college students forms and develops under current new situation of higher education popularization and an important measure to achieve integrated development of college students. Ideological and political education in career planning for college students indeed complies with social development and education rules. Combination of career planning and ideological and political education can better give play to political direction of ideological and political education so as to motivate spiritual impetus of college students and shape their good personality. This paper analyzes the connotation of career planning for college students, discusses the relationship between career planning and ideological and political education, and puts forward vital significance of career planning on ideological and political education.

In view of the arrival of the era of knowledge economy, colleges' continuous enrollment increase gives rise to a very large challenge to employment of graduates. How to further strengthen and improve ideological and political education of college students is a big issue faced by ideological and political education. Colleges should regard people first and combine actual situations of college students to solve practical problems of college students and gain expected effects in the process of ideological and political education. Nowadays, ideological and political education is closely related to employment of college students. Thus, career planning for college students is of great significance for ideological and political education.

\section{Connotation of career planning for college students}

Career planning means one confirms his ideal career goal through comprehensive analysis of his interests, hobbies and abilities, combination of features of current ear and on the basis of predicting, analyzing and summarizing subjective and objective conditions of his career, and makes proper arrange in order to fulfill the objective. It is required to make college students fully cognize themselves through implementing career planning, establish correct outlook on life and values based on the precondition of objective analysis of environment, fully overcome various difficulties in career planning and achieve employment success with rational methods and effective measures. The primary task of career planning is to practically help college students carry out self-analysis and cognition. It is required to make college students continuously improve abilities, plan their future more rationally, boost their personal quality and really experience success. The main objective of career planning is to practically respect subjective status of college students so as to arouse their potential, achieve all-round development and mutual unification of personal ideal and serving the society. Career planning for college students includes very rich and vivid ideological and political education resources which can display the principle of ideological and political education (i.e. people first and connection with actual situation of college students), and adapt requirements of social development for college education resources, subject consciousness improvement and individuation demands of college students and can well combine universal education and individual education.

\section{Relationship between career planning for college students and ideological and political education}

Firstly, education direction of career planning for college students and ideological and political education is consistent. The former is a process in which one formulates the ideal scheme for future development trend according to changes in subjective and objective factors based on cognition and 
analysis of ideal and reality. Then, one confirms his career development task, works out rational training and education plans to achieve perfection of career objective so as to grow to a talent with all-round development in the new era. The objective of ideological and political education is to practically help college students form correct outlook on life and values, promote them to become useful high-qualty personnel and fulfill harmonious sustainable development of the whole society based on fulfilling self-development. Therefore, the two have completely consistent direction and both hope to facilitate comprehensive sustainable development of college students.

Secondly, career planning for college students and ideological and political education own close contents. Career planning can not merely help college students find out the suitable jobs according to their conditions, but effectively assist them in forming correct outlook on life and values, planning future development and specifying future struggling objective. The most important task for ideological and political education is to practically help college students form correct outlook on life and values, facilitate them to better arrange their life, fulfill individual new development and then promote harmonious development of the whole society. In view of this, career planning for college students and ideological and political education have close contents and respective emphases.

Thirdly, career planning for college students and ideological and political education are mutually influenced. College student cultivation quality is not just judged by career planning and employment, but by implementation of career planning through focusing on ideological and political education and adjustment according to current situation and demand of ideological and political education. In career planning, elememts related to ideological and political education should be properly added. The flexibility and practicability of career planning can be utilized to improve ideological and political education effects. It thus can be seen that career planning for college students and ideological and political education are mutually influenced and promoted.

\section{Important significance of career planning on ideological and political education}

\section{(I) Career planning displays the purpose of ideological and political education - all-round education}

Chinese colleges cultivate successors of socialism with Chinese characteristics. This means college students should not merely master corresponding scientific cultural knowledge and skills, but also own excellent ideological and ethical standards, socialist outlook on life and values. Career planning is an important constituent part of ideological and political education and can thus reflect the purpose of all-around education. Career planning in colleges should not just comprehensively analyze external environment, but also objectively cognize and analyze themselves, carry out vocational education for college students and help them confirm their vocational education objectives and implement them. This process can reflect all-around education purpose of ideological and political education. Career planning for college students can make them know their individual development direction and objective more clearly, and reach self-evaluation and correction in the growing process so as to practically shorten the confusion period, guide them to establish scientific and feasible career objectives, avoid confusion and fulfill the propose of comprehensive quality improvement and all-round education.

\section{(II) Career planning is an important carrier of innovation of ideological and political education}

Career planning in college students us a long-term systematic project and urgently needs joint participation of college students, parents college teachers and relevant persons in society. Only when the above factors form resultant force can college students be driven to fulfill all-round development. College students are the subjects of career planning, the communities of society, college and family benefits and the subjects of society, colleges and families focus on. Based on career planning of college students, it is required to continuously drive mutual communication among society, college students and their parents and then fulfill interactions between colleges and students, among college students and between colleges and society. It is required to practically give play to educational function of colleges, society and families, and apply exchange, communication 
and interaction to master ideological dynamics of college students, listen attentively to them, enhance understanding and trust and gain more ideal effects.

\section{(III) Career planning makes the objectives of ideological and political education tend to materialization}

The fundamental objective of college education is to cultivate constructors and successors with all-round development for socialism with Chinese characteristics. So, correct thoughts should be used for guidance and education so as to make college students always stick to socialism direction and struggle for it. In traditional sense, target orientation of integrated higher education is too narrow, which is mainly reflected in empty preach lacking persuasion in ideological and political education. Besides, it cannot approach actual situations of the objects receiving education, keep away from reality and makes college students feel long distance. Once diversity feature and higher education objective of the objects receiving education are not fully considered, it is difficult for ideological and political education to reach expected effects. Rational career planning should be carried out through college students. College students set career development goal through self-cognition and then fulfill self-affirmation, self-growth and self-actualization. To search to the bottom, it is an education mode which always runs through whole college life through all-round development of college students. The main form of career education is development. It can not only well help college students know themselves and their occupation orientation, but also cultivate their career planning and decision-making ability, and effectively assist them in discovering and excavating their inherent potential so as to adapt current environment and environment and promote fulfillment of individual career development objective. Career planning of college students is based on individual goals and individualized development. . Career planning well reflects ideal and belief education. The two complement each other. Fusion of ideal, faith, patriotism, ideological and moral education in college teaching can adapt individualized development demand of college students and help college students achieve change form career exploration period to confirmation period more smoothly. It is required to make ideological and political education objective clearer and improve effects of ideological and political education.

\section{(IV) Career planning drives ideological and political education contents tend to be systematical}

Ideological and political education in colleges should follow the principle of people first and moral education first, and involve ideological and political education in many links of higher education so as to effectively form full-profess education and all-round education. Colleges should apply ideological and political education to shape and cultivate people and really fuse ideological and political education in the whole process of higher education, regard growing and becoming useful persons of college students as the core and achieve respect, understanding and care of students. Contents of ideological and political education mainly include politics, ideology, morality, law, mental health and humanistic education. In teaching practice, career planning has great systematicness and always runs through the whole process of life and study of college students. To be more specific, in the freshman year, colleges mainly set up specialty cognition and formative education and pay attention to analysis and self-orientation of their career. In the sophomore year, colleges mainly set up the education to enrich college students and perfect knowledge structure, and pay attention to designing career of college students to lay a solid foundation. In the junior year, colleges mainly implement practical education and innovative education, pay attention to diagnose career so as to improve quality. In the senior year, colleges mainly set up guidance prior to employment and occupation navigation, and pay attention to career navigation to let college students better select jobs and obtain employment. The above four phases have different requirements, but are mutually connected and complemented. Quite sound career planning mechanism for college students can be established. In view of this, implementation process of career planning for college students is the process of deepening and systematizing ideological and political education. Career planning for college students should focus on how to solve ideological problems and practical problems of college students according to overall requirements of ideological and political education regardless of gradualness and relevance of education contents 
and process so as to make ideological and political education more accord with actual situations and approach life, optimize ideological and political education contents and lay a favorable foundation for forming long-acting system of ideological and political education.

\section{(V) Career planning promotes ideological and political education methods to tend to be diversified}

Career planning can well solve the problems of traditional ideological and political education, i.e. paying excessive attention to infusion and preach, neglecting penetration and interaction. It is necessary to educate college students with consistent contents, ways, standards and requirements. In traditional sense, teachers are dominators in ideological and political education which is dominated by infusion education and neglects the subjective status of college students in ideological and political education. Career planning should fully adapt educational environment changes, transform individual growth needs to internal driving force of ideological and political education, better give play to initiative of college students, display personalized features of higher education and their subjectivity status and make them subtly improve during participation in interactions. This mode well combines universal education and individual education, which practically improves ideological and political education effects, embodies people-oriented concept and completely accords with people-oriented modern education concept.

\section{Conclusions}

In general, it is very necessary to study significance of career planning on ideological and political education. This is not just an inevitable choice of severe employment situation of college students, but also can better carry out ideological and political education, guide college students to implement scientific and normative career planning, enhance ideological and political education and help them better obtain employment.

\section{References}

[1] Lu Zhipeng, Career planning and employment guidance [M] Beijing: Economic Science Press, 2008

[2] Huo Rutao, Guo Baoliang, Career planning and employment guidance of college students [M]. Beijing: China Agriculture Press, 2008

[3] Li hongya, Zhu Tinglan, Ideological and political education in career planning of college students [J]. Helongjiang education, 2009 (1)

[4] Li Rongmei, Current situation and countermeasure of effective interaction between career planning and ideological and political education of college students [J]. Journal of Educational Institute of Jilin Province, 2010 (5)

[5] Tian Xinshan, Problems and solutions of career planning for college students [J]. Journal of Changchun Finance College, 2012 (1) 